\title{
Technology, Trade Sensitivity, and Labor Displacement
}

\author{
John T. Addison,* Douglas A. Fox, $\dagger$ and Christopher J. Ruhm
}

\begin{abstract}
This study examines the relationship between international trade, technology, and exposure to job displacement, using data on displaced workers as well as those at risk of job dislocation. for the two-year sample periods 1986-1987 and 1990-1991. Workers employed in manufacturing industries with elevated import penetration or high shares of R\&D personnel appear to have increased rates of job loss. However. the risk of job loss is materially reduced when a relatively high proponion of employees repon working with computers. The opposing effects on displacement probabilities of R\&D employment intensity and computer-use carry over to the nonmanufacturing sector.
\end{abstract}

\section{Introduction}

The last 25 years have witnessed a substantial growth in inequality in most industrialized nations. In the United States this has taken the form of an increasingly unequal distribution of earnings, whereas in Europe, it has been manifested in a dramatic rise in joblessness.' The sources of these trends have been the subject of much study, with two factors, (accelerating) technological change and heightened international trade, receiving most attention.

Most economists have emphasized the role of technology, arguing that skill-biased technological improvements have reduced the relative wages of unskilled workers in the United States and, given lower levels of economic flexibility, have resulted in substantially higher unemployment for these groups in Europe. Only a minority of researchers believe that international trade has been of key importance, holding that the growth in trade with less developed countries has led to a dramatic increase in the stock of available unskilled workers, thereby reducing the returns to "raw" labor. Trade considerations have nevertheless dominated public debate and preoccupied policymakers; for example, much of the debate over the North American Free Trade Agreement (NAFTA) reflected concerns over its likely effects on domestic wages and job destruction. and on side agreements motivated by a desire to avoid a race to the bottom.

Trade or technology may of course increase wage inequality without causing any unem-

* Deparment of Economics, Darla Moore Scherl of Business. University of South Carolina. Columbia, SC 29208. USA: E-mail ecceaddiodarlabadmacedu; corresponding author.

Economic Research Services. Inc. 4901 Tower Court. Tallahassee, FL 32303, USA: E-mail dfox (Gersnet.com.

\# Bryan School. Unversity of N.C. Greensboro. Greensboro. NC 27402-6165. USA: E-mail c_ruhm Guncq.eda.

We thank. without implicating, two anonymous referes and editor Jonathan Hamilton for helpful comments on an earlier draft.

Received March 1997: accepred July 1999.

' For example, the differential in log wages between the 9oth and the 10 th percentie of U.S. males grew from 1.15 in 1969 to 1.49 in 1989 (Katz, Loveman. and Blanchlower 1995). The unemployment rate of males in OECD-Europe ateraged just $3.4 \%$ over the $1974-1979$ period but rose to $8.1 \%$ between 1990 and 1993 (OECD 1995). Although wage differentials in the Lnited States have recently stabilized and modestly reversed direction. the same is not true of unemploy ment development in OECD-Europe. 
ployment. For example, once the Stolper-Samuelson theorem (1941) is holted on to the factor price equalization model. the rise in the skill premium in rich countries-with the shift in their industry mix toward skill-intensive output-will cause firms to reduce the ratio of skilled to unskilled labor. The equilibrium differential will be one that induces a growth in unskilled worker employment in skill-intensive production that exactly offsets the shrinkage in unskilled worker employment in the declining, labor-intensive sectors. Although the biased technological change story can in principle be deployed to explain almost any pattern of relative wages, the most obvious impact of new machines that do the work of unskilled labor for less is to widen the distribution of earnings.

Moreover, in addition to employment declines in the affected sectors, there will also be (unless wages display an exceptional degree of downward flexibility) permanent layoffs. Such displacements are of particular concern because they have been linked to increases in unemployment and, more fundamentally. 10 substantial and lasting reductions in carnings. ' Yet significantly, despite the lack of research confirming the contribution of increased economic integration to labor displacement, special assistance has for almost 40 years been available through categorical programs geared to those displaced by international trade (namely through Trade Adjustment Assistance and more recently via the NAFTA Transitional Adjustment Assistance Program). ${ }^{3}$ By contrast, special support has generally not been provided to workers dislocated by reason of changes in technology, even though this may be a more important source of job loss and reemployment difficulty. Rather, such support has applied more generally to displaced workers through such vehicles as Title III of the Job Training Partnership Act.

This paper focuses on the link between trade sensitivity, technology, and exposure to job loss. Our goal is to provide a more detailed analysis of probability of displacement than is available in extant treatments that have largely confined their attention to trade variables. Subsequent research shouid examine the consequences of trade and technology-induced displacement by considering pre- and postdisplacement outcomes for displaced workers alongside the earnings development of the nondislocated population who may nevertheless have been affected by heightened international trade or changes in technology. The present exercise represents a first step toward understanding the job-loss component of changes in total employment.

To anticipate our findings, persons employed in manufacturing industries with high. if not rising, import shares and in branches with more advanced technology (as indexed by R\&D employment intensity and the computer investment ratio) confront a higher risk of displacement than their counterparts in sectors that are more sheltered from imports and less technologically advanced. Conversely, holding these factors constant, individuals working with computers are consistently less likely to be displaced. Thus, just as with recent explanations of the growth in the return to education, computer facility on the part of the worker appears to deliver a competitive edge. Interestingly, as with manufacturing, risk of displacement in nonmanufacturing

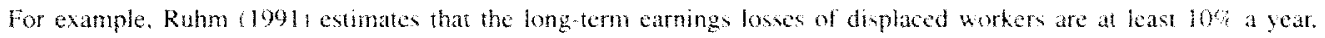
and Jacobson. LaLonde, and Sullivan (1993) indicate a stll larger reduction in eaming of $25 \%$ for highe tenure (more than five years of service) workers who change johs.

One rationale for these progtams is it is equitable to compensate those whose loss of employment makes possible the societal gains resulting from increasngy npen economies. The equity case for also been bultessed by second-best

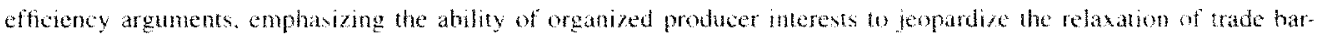
riers. Within the Furopean Union. the erecton of atvhitions social action progratus has also hech seen as essential to the achievement of conomic integration. These arguments are reviowed by threnberp 1 lo94) and Bean. Bentolik. Bertola and Dolado 19981 .
} 
industries is positively related to R\&D employment intensity and is negatively associated with working with computers.

\section{Previous Literature}

In recent years, extensive literature has investigated the impact of increases in international trade on the relative wages-and less frequently, the employment levels-of less skilled workers. The approach commonly adopted by labor economists has involved calculating the "factor content" of imports and exports to estimate the changes in factor endowments resulting from trade. These changes are then combined with assumed demand and supply elasticities of labor to determine how trade has affected equilibrium wages. ${ }^{4}$ Conversely, trade economists have more frequently focused on changes in relative prices, arguing that the threat of import competition could affect prices, and thence domestic wages and employment, even in the absence of trade flows. ${ }^{5}$

Generally, the effect of technological change on inequality has not been estimated directly. Rather, the proportion of the time trends not attributed to changes in trade or other observed factors (e.g., demographic characteristics and institutional events such as union decline) is assumed to result from skill-biased technological change. This residual approach is unsatisfactory, not least because errors in calculating the effects of the other factors will lead to potentially serious biases in the estimated effects of technology. As a result, researchers (Berman, Bound, and Griliches 1994; Machin 1996; Berman. Bound, and Machin 1997) have increasingly attempted to include direct proxies for the effects of technology. This is the approach used in our analysis. The technology studies generally report that increases in the ratio of skilled to unskilled worker employment are primarily an intraindustry phenomenon-rather than being explained by sectoral differences as might be the case if trade were the cause-and that the proxies for technology are important determinants of these within-industry movements.

As noted above. employment reductions, whether caused by trade or technology, are likely to be accompanied by falling wages and job terminations. Other things being equal, greater wage flexibility will be associated with smaller numbers of permanent layoffs. Conversely, increasing employment may coexist with rising import shares if foreign production is more elastic than domestic supply. Nevertheless, if product demand is controlled, growth in imports will generally be associated with some displacement. The effect of technological change is more ambiguous. New technologies reduce the demand for labor, at given levels of output, but product demand will increase as cost savings are passed on to customers. Displacement per se is yet more complicated because net employment could decline without permanent layoffs if firms are able sufficiently to reduce the rate of hires or increase quits. ${ }^{\text {? }}$

The consensus of the early literature (Grossman 1987; Mann 1988; Dickens 1988) was that rising imports were responsible for, at most, only a small proportion of the domestic em-

\footnotetext{
${ }^{4}$ A series of articles in the Summer 1995 issue of the Journal of Ecomonic Perspectives (Freeman 1995: Richardson 1995; Wood 1995) provides an excellent introduction to these issues. Useful alternative sources are Burtless (1995) and the January 1995 issue of the Eeonomic Policy Review, published by the Federal Reserve Bank of New York. which is devoted to an examination of wage trends in the United States.

seamer (1994) offers a forceful exposition of this argument.

*Very different results are reported, however. by Mishel and Bernstein (1996).

'Kletzer's (1995a) study of trade and job displacement attempts to account for these types of labor market transitions.
} 
ployment reduction observed in trade-sensitive industries. A number of more recent studies of the effect of trade on low skilled worker wages and employment also point to very modest effects (Sachs and Shatz 1994). Taken in conjunction with the phenomenon of an increased relative use of skilled workers across industry at a time of rising skill differentials, most observers have concluded that biased technological change, rather than international competition, is the dominant factor explaining changes in employment and relative wages over the last 15 years. ${ }^{\circ}$ But if this is the orthodox view, a number of empirical analyses, using both quantitybased and price-based measures of import competition, point to much stronger trade disemployment effects (Freeman and Katz 1991; Revenga 1992). ${ }^{9}$

In marked contrast with the burgeoning literature on the "distributional" consequences of heightened trade and technological change, there has been less investigation of the causes of displacement. The issue of trade and displacement has attracted some scrutiny, but we know of no studies investigating the contribution of technology to worker dislocation.

Using data from the Displaced Worker Supplement (DWS) to the January 1984 Current Population Survey (CPS), in conjunction with the NBER Trade and Immigration data file, Kruse (1988) reports that an increase in the import share of the worker's displacement industry is positively related to the subsequent duration of joblessness. He argues that this occurs because workers displaced from high import change industries have characteristics that are associated with increased employment difficulties and because import growth is linked to industry decline. ${ }^{10}$ Shelburne and Bednarzik (1993) report that trade-sensitive industries are geographically concentrated, accentuating the effect of job losses on local unemployment rates and making it more difficult for displaced workers to adjust. (The authors note, however, that the geographical concentrations of export-sensitive industries and import-sensitive industries do not coincide.)

Addison, Fox, and Ruhm (1995) provide a wider ranging descriptive treatment of the relationship between trade sensitivity, displacement rates, and reemployment outcomes. Their analysis, which is restricted to workers employed in or displaced from manufacturing industry, uses data from the January 1988 DWS matched with industry trade data provided by the U.S. Department of Commerce for the period 1982-1986. The authors show that although exposure to trade is positively associated with probability of job loss, there is little to suggest that either import or export penetration rates are correlated with postdisplacement adjustment problems, as indexed by subsequent joblessness, earnings, or health insurance benefits.

Finally, Kletzer (1995a) has examined the effect of trade sensitivity on displacement rates, reemployment probabilities, and changes in earnings. Her displacement data are taken from the 1984 through 1992 DWSs and are matched with trade data contained in the NBER Trade and

\footnotetext{
* The link between wages and employment is quite direct. For example. Juhn, Murphy, and Topel (1991) show that both wages and work hours teclined over time for those at the bottom of the U.S. earnings distribution.

+ Borjas and Ramey (1995), in a notable challenge to orthodoxy, offer a quantily-based extension in which it is reported that international rade could explain roughly one-half the decline in employment in highly concentrated industries. The authors argue that the observed increase in wage inequality in the United States can be directly linked to this phenomenon. because these industries are believed to share rents with their workers and also to employ a disproportionate share of less educated individuals who bear the brunt of the adjustment to tising imports. The principal quantitybased study arguing that trade is the root cause of the fall in demand for less skilled workers in developed countries is Wood (1994). Other studies emphasizing the role of trade are Borjas and Ramey (1994), Leamer (199.4), and Schmitt and Mishel (1996).

Similarly, Bednarzik (1993) indicates that workers in import-sensitive industries are more likely than those in exportsensitive industries to be temale. black, Hispanic, young. and employed part time, and correspondingly less likely to be college graduates and to hold professional, managerial, or technical johs.
} 
Immigration data file. Industry-level displacement probabilities are shown to be increasing (decreasing) with the growth in imports (exports), although the import change coefficient estimate is statistically insignificant." Kletzer also reports statistically insignificant associations for both trade variables (now expressed in levels form) on reemployment probabilities or postdisplacement outcomes. ${ }^{2}$

Overall, the impact of trade on displacement probabilities appears rather muted, and we know almost nothing about the effects of technology on worker dislocation. Given the political sensitivity of displacement, our limited understanding of its causes, and the potential for evidence on trade- and technology-induced displacement to add value to the wider literature briefly reviewed here, further examination of the links between trade, technology, and displacement would appear amply warranted. In what follows. we offer a preliminary treatment, focusing on displacement probabilities."

Our investigation of the effects of international trade will be quantity-rather than pricebased. examining the effects of import and export penetration rates on displacement probabilities. Trade theorists might prefer the use of price-based indicators, under the assumption that factor prices are dictated solely by relative goods prices (and sectoral total factor productivity), raising the possibility that the threat of imports might reduce wages without any trade flows. However, there are a number of problems with the price-based approaches that may be more severe than those attaching to their quantity-based counterparts. First. factor price equalization. which underpins the exclusive focus on relative prices, assumes that wages will be unaffected by domestic labor market developments. This assumption is clearly at odds with the substantial body of evidence indicating that earnings differentials are influenced by local changes in the demand and supply of labor (e.g., cohort changes in the size of the labor force, local or crosscountry migration, and changes in educational attainment, inter alia). ${ }^{14}$ Second, changes in relative prices may reflect developments that would have occurred in the absence of increased trade, such as changes in tastes (Krugman 1995). Third, there are difficulties with measuring prices in the various sectors. At one level, this problem arises in aggregating import and export series from the four-digit standard industrial classification (SIC) level to match displacement data at the three-digit Census of Production level (Kletzer 1995a. p. 11). More generally, goods are likely to be heterogeneous within statistically defined sectors (Wood 1995, p. 73). Finally, the results of empirical examinations that focus on price changes are quite fragile to changes in measurement and specification. ${ }^{15}$ In short. results from price studies are "far from the final word" (Freeman 1995, p. 29). The quantity-based approach can also be criticized, as has already

\footnotetext{
1: Kletzer (1995a) also provides results for a separate spectication that captures trade sensitivily via changes in the domestic prices of impon goods relative to the aggregatc price kevel, with controls for changes in GDP and industry. The coefficient estimates for the import neasure are negative-suggesting that as the relative prices of imports fall and imports become more competitive, displacement rises-but again fail to achieve significance at the $10 \%$ level.

" Haveman (1993) (cited in Richardson 1995), using a price-based measure of trade pressure, finds that workers displaced from tradeables industries in decline suffer longer joblessness than other displaced workers and also greater (relative) earnings losses.

A multivariate analysis of the conseguences of trade- and techology-induced displacement for joblessness, inter alia. that uses similar but less comprehensive data than is deplnyed here to capture risk of displacement is provided in Addison. Fox, and Ruhm (1996). That study fails to suggest that heightered exposure to job loss via greater industry impon penetration or elevated computer investment translates into unfavorable postdisplacement outcomes.

1: See Katz and Murphy (1992) for an example of research emphasizing hou changes in domestic supply and demand have aftected relative wages.

${ }_{15}^{5}$ For example, see the debate hetween Lawrence and Slaugher (1993) and Sachs and Shatz 1994 ) on whether or not computer prices should be included in the calculation of relative price changes.
} 
been acknowledged. Yet we believe that the problems of price-based investigations are likely to be still more severe. and we are reassured by Krugman's (1995. p. 35) theoretical argument to the effect that the factor content analysis is "justified in the context of a general equilibrium model when the trade share is sufficiently small."

\section{Data Description and Methodology}

This analysis uses data from the DWSs to the January 1988 and January 1992 CPSs. The DWS contains retrospective information on individuals permanently losing their jobs during the previous five years. ${ }^{16}$ Our samples include those displaced during the two most recent years of the survey-that is, 1986-1987 and 1990-1991, respectively-by reason of plant closings. slack work, or abolition of shift or position, together with those who were employed at the survey date and did not report a job loss during the previous five years. ${ }^{17}$ The greater part of our analysis will focus on manufacturing displacement and employment given the richer array of data (particularly that on imports and exports) available at this level, but we will also offer some comparative results with nonmanufacturing. Apart from reason of displacement and sector. the other main restriction imposed on the data was that the displaced/employed individual be aged between 25 and 60 at survey date to avoid sampling labor market experiences dominated by rapid turnover and the retirement decision, respectively.

This inquiry also uses NBER trade data for 1986-1987 and 1990-1991. ${ }^{18}$ The underlying data provide the value of U.S. imports, exports, and domestic product shipments, from 19581994, for four-digit (1972) SIC manufacturing industries. The two periods selected were chosen to correspond to the intervals of displacement identified here. The SIC-based trade data had to be aggregated to obtain consistency with the industry basis of the DWS, which conforms to the Census of Production Industrial Classification (CPIC) system. Aggregating the four-digit trade data to the most detailed industry level available in the CPIC system (the three-digit level) yielded samples of 75 manufacturing industries for both periods.

The import penetration rate for each industry is defined as the value of imports of goods into the United States divided by domestic supply (namely, total imports plus domestic product shipments for the industry). The corresponding export penetration rate is the ratio of U.S. exports to total U.S. product shipments. Annual import and export rates, for each industry, were averaged over the two-year sample periods to produce the main trade measures used in this analysis. Part of our analysis will also include changes in imports and exports. measured as the percentage point difference between the respective penetration rates in 1990-1991 and 1986-1987, in conjunction with data from the 1992 DWS.

Finally, consonant with the skill-biased technological trade literature, we merged the displacement and trade data with three industry technology measures: the ratio of computer expenditures to total investment, the employment of scientists and engineers as a proportion of total employment, and the proportion of individuals reporting using a computer at work. Information on the computer investment ratio was available for manufacturing industries alone and

\footnotetext{
${ }^{16}$ The surveys. which have been conducted biennially since 1984, are well described elsewhere isee Herz 1990 ).

It is now conventional in the displacement hiterature to confine attention to the last wo years of the DWS for reasons associated with recall bias and question design: on which. see Farber (1993).

1* We like to thank Rohert C. Feenstra of the University of Calitornia-Davis, and the NBER. for making these data available to us.
} 
then only for $1987 .{ }^{19}$ Data on $R \& D$ employment-intensity were available (for both manufacturing and nonmanufacturing industries) for each year between 1983 and 1992 from the CPS Outgoing Rotation Group Earnings Files. ${ }^{20}$ We used the annual ratios for 1986-1987 and 19901991 to construct average values that coincided with the DWS intervals. We also constructed an $R \& D$ change variable, which was equal to the difference between the $R \& D$ employment ratios between the 1990-1991 and 1986-1987 intervals, again using this measure in conjunction with the 1992 DWS. Information on the use of a computer at work was obtained from a supplement to the October 1989 CPS. This supplement dealt primarily with school enrollment but also included questions related to the kinds of computer equipment owned or used by the respondent. The proportion of computer users was determined by calculating the share of individuals employed in each industry responding positively to the question "Does [the respondent] directly use a computer at work?" $2 !$

The probability of job loss was determined from econometric estimates for a dichotomous dependent variable taking the value of one for CPS respondents who stated that they experienced a permanent layoff during the two-year sample period and zero if no job loss was reported. ${ }^{22}$ The job-loss equations were modeled as maximum likelihood probit equations. Most of our specifications include controls for demographic and human capital variables, obtained from the parent CPS. These comprise dummy variables for sex, race, marital status, completed years of schooling (five categories), the presence of minor dependent children in the household, and a quadratic in years of age-all measured at survey date. Additional (continuous) variables obtained from other data sources are the average state unemployment rate and union density, calculated as the proportion of individuals in the industry covered by a collective bargaining agreement, each averaged over the two-year sample periods. ${ }^{23}$ The final regressor is the change in domestic product demand. This variable is measured as the change in product shipments within each of the sample periods and is obtained directly from the trade data.

Table 1 provides the descriptive statistics. The data refer throughout to displaced manufacturing workers. It can be seen that the displacement rate increased from $6.6 \%$ percent in 1988 to $9.2 \%$ in 1992 . Over that interval, import penetration rose modestly from 12.4 to $13.3 \%$, and export penetration more substantially from 8.1 to $12.1 \%$. The demographic and skill profiles of the samples are roughly comparable across time periods, although industry union density falls from 25 to $22 \%$. Only slight reductions in the unemployment rate are recorded.

\footnotetext{
${ }^{19}$ We thank Eli Berman of Boston University for providing us with this information. which originally came from the Census of Manufactures. Some industries did not report computer investments, and we used the following procedure to deal with the missing data. If information was available for some, hut not all, of the four-digit SIC industries included in the three-digit Census classification, the investment ratio was calculated over just the nonnissing components. If the computer data were not available for all of the SIC industres-w which was the case for one of the Census industries (namely, 230)--the computer investment ratio was assigned a zero value. For evidence that computerization played an important role in most technological innovations during the 1980s, see Mark (1987).

${ }^{20}$ We thank Barry $T$. Hirsch of Florida State University for providing us with this material, derived from the CPS ORG files.

"A similar survey was conducted as a supplement to the October $1984 \mathrm{CPS}$, but in this case, the question pertaining to computer-usage at work was not asked.

22 It is thoroughly conventional to use the number of workers employed at the survey date to identify the at-risk group (see Farber 1997). For an alternative approach, see Kletzer (1995b).

${ }^{23}$ The information on unemployment rates was obtained from the U.S. Department of Labor. Bureau of Labor Statistics (various issues), and the union data from Hirsch and Macpherson (1993).
} 


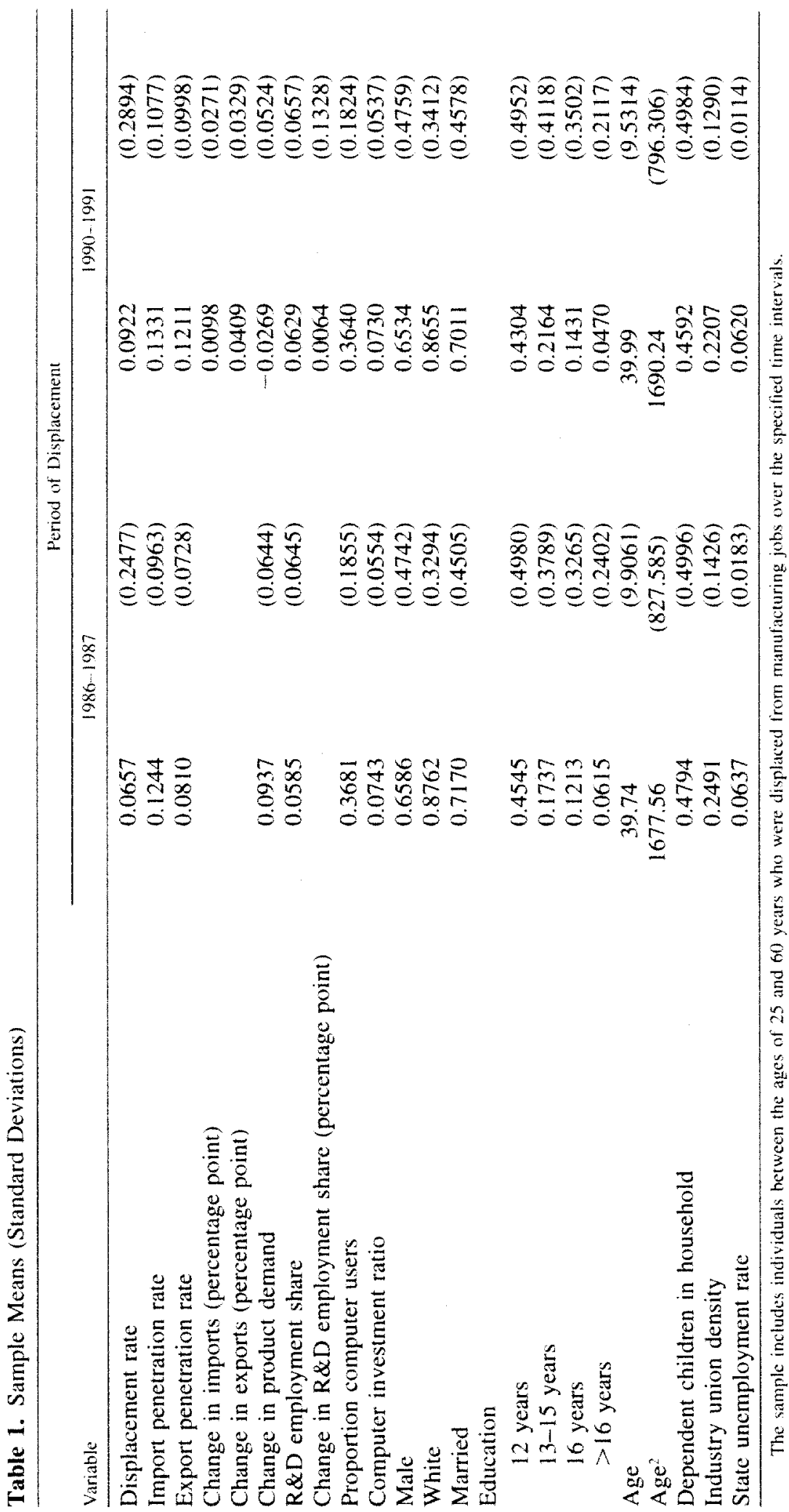




\section{Findings}

Probit models estimating the probability of job loss are summarized in Table 2. Both the probit coefficient estimates and marginal effects estimated at sample means (the partial derivatives) are provided. Specification (a) examines the effect of trade sensitivity. ignoring all the other determinants. In both periods, the level of import penetration is positively related to displacement probabilities, and the marginal effects are very similar. The effects of export penetration, on the other hand, are of opposing sign, but neither coefficient is estimated with precision. ${ }^{24}$ Controlling for changes in product demand. Specification (b) does not materially affect the point estimate for import penetration in either sample period. while the effect of increased product demand in reducing layoff probability is clearly better determined in the later interval. The addition of demographic and human capital controls in Specification (c) reduces (but does not eliminate) the increase in displacement rates associated with imports.

Specification (d) adds to the model three technology variables: R\&D employment intensity. the computer investment ratio, and the proportion of employees working with computers. Their inclusion further decreases the magnitude of the import share coefficient. whereas the export share coefficient increases and achieves statistical significance in the earlier period. More important are the very different effects of the technology variables on risk of job loss. Both R\&D employment intensity and the computer investment ratio are positively associated with probability of displacement. whereas computer-use is negatively related to the risk of job loss. For the earlier interval, only the last variable is well determined, but in the later period. two out of three technology variables are strongly statistically significant.

These findings suggest that exposure to both international trade and technological change may increase probabilities of job loss. However, the most interesting result is that those with computer skills are much less subject to layofi. after controlling for the trade and other technology variables. This result has not to our knowledge been presented before in the displacement literature, but it is entirely consistent not only with skill-biased technological change but also with Krueger's (1993) analysis of the covariation of computer-usage and occupational earnings. ${ }^{2 s}$ We will return to this theme below when we report results of a comparison between manufacturing and nonmanufacturing industry.

Specification (e) of the table examines whether changes in trade sensitivity and technology affect risk of joh loss. Given the rather short sample periods, changes in the trade measures and in R\&D employment intensity (the sole technology indicator for which we have a time series) are measured as percentage point differences between the 1990-1991 and 1986-1987 average values of the respective variables. It can be seen that growth in imports is negatively associated with risk of job loss, and conversely for export growth of job loss. For its part, the change in R\&D employment intensity is negatively associated with displacement risk, although the point

\footnotetext{
it Because values for the trade and technology variables are estimated at the industry level and then attached to individual data. the standird errors of the coetficient estimates may be underestimated. Accordingly, conclusions regarding statislical significance should be treated with caution.

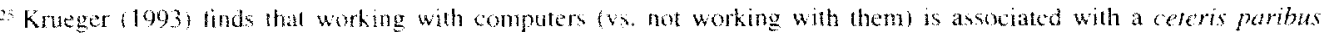
increase in wages of between 15 and $20 \%$. His estimate imply that the expansion in computerusage in the 1980 can explain up to $50.5 \%$ of the observed increase in the rate of return to edacation. Krueger interprets his results as providing support for the notion that technological change has contributed materially 10 recent changes in the wage structure. However, see Divardo and Pixchke (1997) for a dissenting view.
} 
estimate is poorly determined. In broad terms, the results for changes are opposite in sign from those obtained for levels.

Using the estimates contained in Specification (d) as our preferred specification, we now illustrate the effect of discrete changes in the trade and technology variables on the risk of job displacement. For imports and exports, we predict the effect on displacement probabilities of going from penetration rates of $0 \%$ to $20 \%$. In the case of the proportion of computer users, the assumed change is from $25 \%$ to $50 \%$. For both $R \& D$ employment intensity and the computer investment ratio the move is from $0 \%$ to $10 \%$. In each case, the changes accord in a very rough way with movements of one standard deviation below and one standard deviation above the mean of the relevant variable. These effects are calculated by estimating displacement rates for each individual, with trade or technology variables assigned the postulated values, and then calculating the average probability across all sample members. Results of these simulations are detailed in Table 3.

It can be seen from the table that the effects of changes in trade and technology on displacement rates are generally rather large. For the earlier period, increasing the import penetration rate from $0 \%$ to $20 \%$ is predicted to raise displacement probabilities from $5.6 \%$ to $7.1 \%$, an increase of $25 \%$. In the later period, a corresponding change in imports raises the predicted displacement rate from $8.6 \%$ to $9.5 \%$ a $10.7 \%$ increase. As already discussed. export exposure is also positively related to displacement risk; however, the predicted impacts are very sensitive to the choice of specification and time period.

For the earlier period, the assumed increases in R\&D employment and the computer investment ratio yield more modest shifts in expected displacement probability of 3.6 and $13 \%$, respectively. Conversely, a doubling of the proportion of employees working with computers lowers expected displacement risk by no less than $31.6 \%$. For the later interval, the effects are predicted to be larger-increasing by $33 \%$ for the R\&D measure and $14.5 \%$ for the computer investment ratio, while the risk of job loss falls by $34.4 \%$ for those working with computers. Based on this evidence. we conclude that import (and export) sensitivity and the conventional indicators of technological advance are associated with relatively large increases in displacement rates. In the context of technology, again note the strong countereffect of working with computers, which is observed across both sample periods. That being said, our findings are necessarily qualified by the sensitivity of the predicted effects of the trade measures. particularly exports, across periods. ${ }^{*}$

As a final issue, we were concerned with the representativeness of our results for the economy as a whole. In particular. the results could be quite different for nonmanufacturing workers. The problem is that we do not have data on trade, changes in product demand, or the computer investment ratio for this sector. Nevertheless, we can estimate a probability of displacement equation across the two sectors (manufacturing and nonmanufacturing) for a specification that contains two technology variables-R\&D employment intensity and the

\footnotetext{
2* The demographic and other cowariates merit brief attention; see the Appendix for full detaits. For the carlice period. all of the demographic controls are poorly determined and just two of the education dummies are significant. For the later period. most of the demographic and all of the education tariables are statistically significant. Greater labor market slack is. however. consistently associated with higher risk of layoff. Interestingly. the coeficient estimate for industry unton density is negative and statistically significant in the later period. But the inforence that unionism is associated whth reduced risk of displacement is clouded because the densily variable will reflect industry compositon. For example. union densily is positively related to firm size and firm age. fomitted factor that have been linked negatively uith plant closings (see Dunne and Macpherson 1994: Freman and Kleiner 1999).
} 


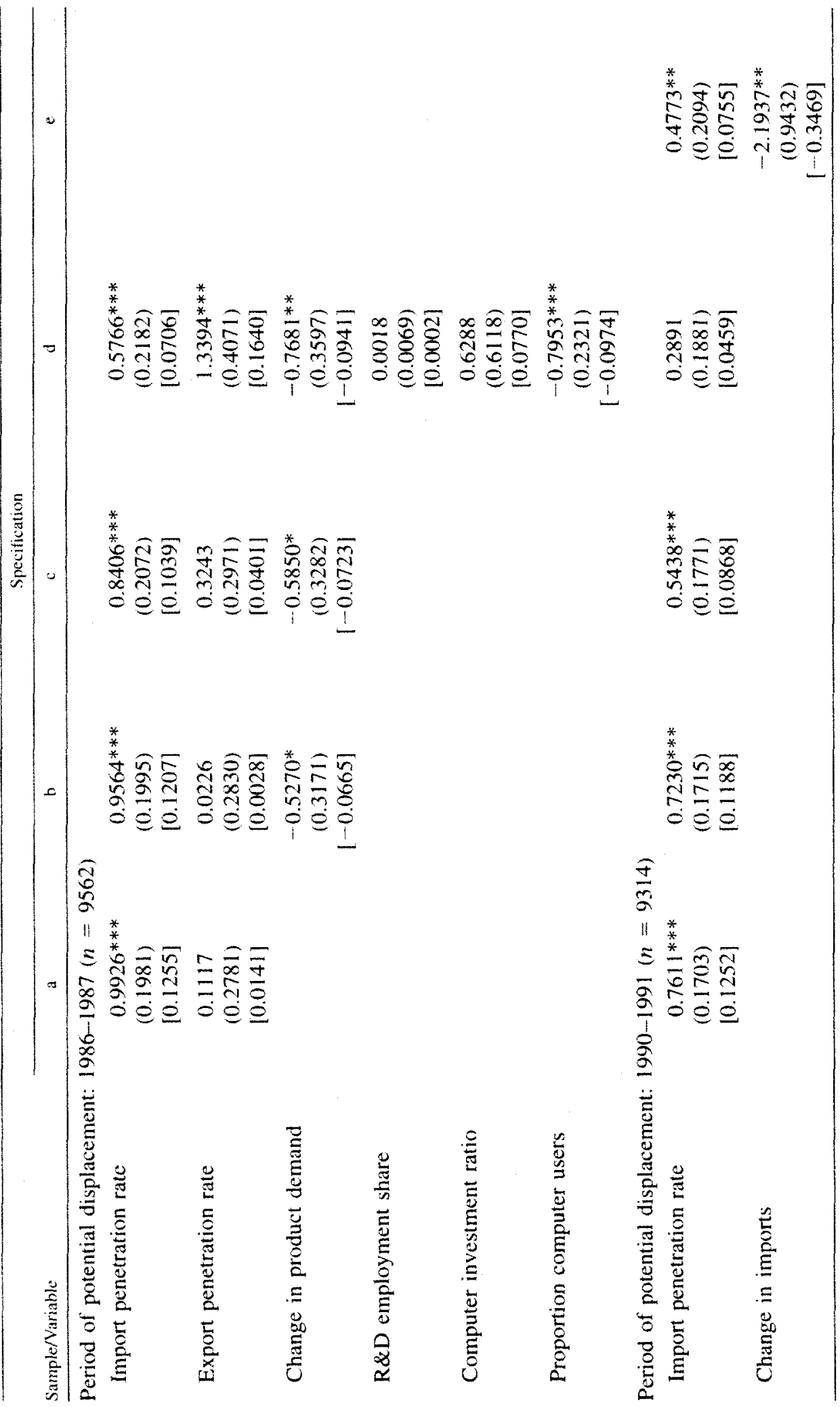




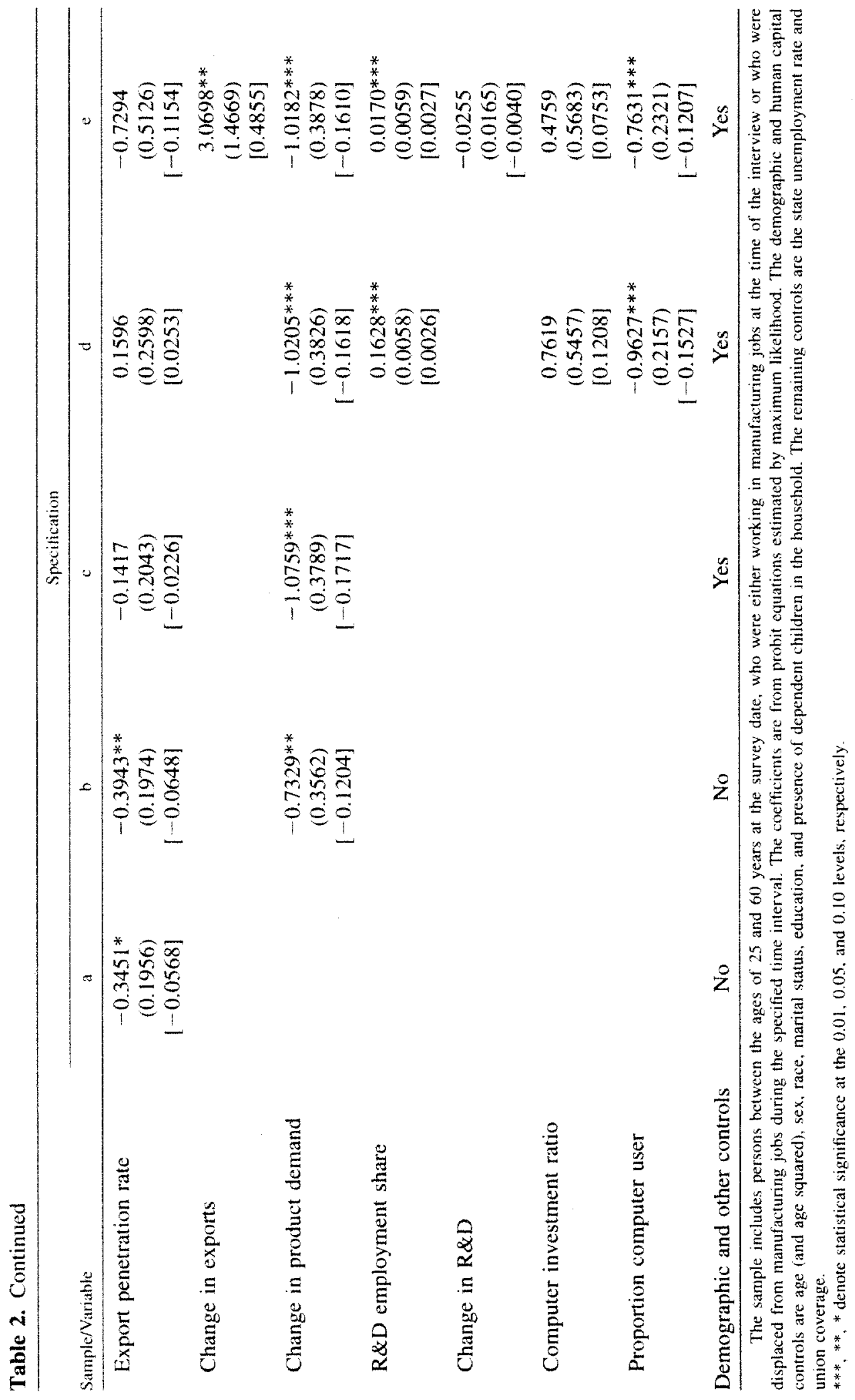


Table 3. Predicted Displacement Probabilities at Different Trade Penetration Rates and Values of the Technology Indicators

\begin{tabular}{ccc}
\hline & \multicolumn{1}{c}{ Period of Potential Displacement } \\
\cline { 2 - 3 } Assumed Covariate Values & $1986-1987$ & $1990-1991$ \\
\hline $0 \%$ Import penetration rate & 0.0564 & 0.0858 \\
$20 \%$ Import penetration rate & 0.0705 & 0.0950 \\
$0 \%$ Export penetration rate & 0.0533 & 0.0892 \\
$20 \%$ Export penetration rate & 0.0884 & 0.0943 \\
$0 \%$ R\&D employment share & 0.0644 & 0.0785 \\
$10 \%$ R\&D employment share & 0.0667 & 0.1043 \\
$0 \%$ Computer investment ratio & 0.0601 & 0.0836 \\
$10 \%$ Computer investment ratio & 0.0679 & 0.0957 \\
$25 \%$ Proportion of computer users & 0.0787 & 0.1117 \\
$50 \%$ Proportion of computer users & 0.0538 & 0.0733 \\
\hline
\end{tabular}

Predicted displacement values are calculated from the probit estimates of Specification d in Table 2.

proportion of computer users-as well as the full vector of demographic/human capital covariates and the controls for union coverage and the state unemployment rate. Summary results of this exercise are reported in Table 4 for the two technology variables. We again find that the $\mathrm{R} \& \mathrm{D}$ employment share is positively and the computer usage variable negatively associated with displacement probability. Both variables are well determined, and the marginal effects are roughly the same order of magnitude across sample periods for each sector.

\section{Conclusions}

Previous research has highlighted the importance of international trade and technological change as sources of secular changes in wage inequality and unemployment. Yet none of the prior literature has focused on job displacement, a potentially important component of these trends and one that has received particular attention from policymakers and the public. This analysis provides evidence that the risk of job loss is relatively high for workers employed in industries investing heavily in computer technologies, and with high $R \& D$ employment intensity, and for those with substantial exposure to import competition. On the other hand, the relation between exports and risk of job loss is clouded by its sensitivity to specification and time period.

Another finding of considerable interest is that workers who use computers at work face considerably lower risk of job loss. To our knowledge, this result has not previously been reported in the displacement literature. We interpret this measure as an indicator of skill-biased technological change.

Although most of our analysis focuses on manufacturing, we also estimated a more parsimonious displacement probability equation for both manufacturing and nonmanufacturing workers. This exercise confirmed the result that $R \& D$ employment intensity is positively associated with risk of job loss, while working with computers materially lowers workers' exposure.

The bottom lines of this inquiry are twofold. First, both trade and technology are im- 


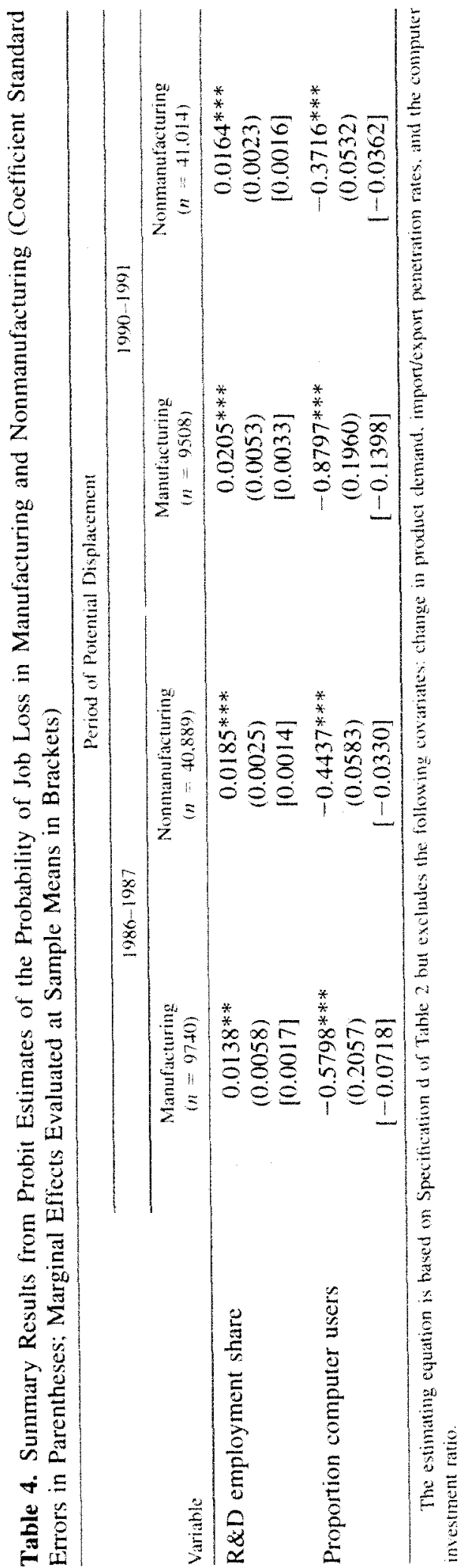


portant sources of involuntary job loss. Second, despite the considerable degree of wage flexibility observed in the United States, it remains insufficient to prevent substantial layoffs. For the future, analyses of the type presented here must be extended to cover the consequences of both trade- and technology-induced displacements on subsequent earnings development. 


\section{Appendix}

Detailed Probit Estimates of the Probability of Job Loss (Asymptotic Standard Errors in Parentheses)

\begin{tabular}{|c|c|c|}
\hline \multirow[b]{2}{*}{ Variable } & \multicolumn{2}{|c|}{ Period of Potential Displacement } \\
\hline & $1986-1987$ & $1990-1991$ \\
\hline Constant & $\begin{array}{l}-1.2581^{* * *} \\
(0.3922)\end{array}$ & $\begin{array}{r}-0.7002^{*} \\
(0.3636)\end{array}$ \\
\hline Import penetration rate & $\begin{array}{l}0.5766^{* * *} \\
(0.2182)\end{array}$ & $\begin{array}{c}0.2891 \\
(0.1881)\end{array}$ \\
\hline Export penetration rate & $\begin{array}{l}1.3394 * * * \\
(0.4071)\end{array}$ & $\begin{array}{c}0.1596 \\
(0.2598)\end{array}$ \\
\hline Change in product demand & $\begin{array}{c}-0.7681^{* *} \\
(0.3597)\end{array}$ & $\begin{array}{l}-1.0205^{* * *} \\
(0.3826)\end{array}$ \\
\hline R\&D employment share & $\begin{array}{c}0.0018 \\
(0.0069)\end{array}$ & $\begin{array}{l}0.0163^{* * *} \\
(0.0058)\end{array}$ \\
\hline Computer investment ratio & $\begin{array}{c}0.6288 \\
(0.6118)\end{array}$ & $\begin{array}{c}0.7619 \\
(0.5457)\end{array}$ \\
\hline Proportion computer users & $\begin{array}{l}-0.7953^{* * *} \\
(0.2321)\end{array}$ & $\begin{array}{l}-0.9627^{* * *} \\
(0.2157)\end{array}$ \\
\hline Male & $\begin{array}{c}-0.0529 \\
(0.0439)\end{array}$ & $\begin{array}{c}-0.0307 \\
(0.0408)\end{array}$ \\
\hline White & $\begin{array}{c}-0.0409 \\
(0.0593)\end{array}$ & $\begin{array}{c}-0.1292^{* *} \\
(0.0514)\end{array}$ \\
\hline Married & $\begin{array}{l}-0.1664 * * * \\
(0.0497)\end{array}$ & $\begin{array}{c}-0.1082^{* *} \\
(0.0444)\end{array}$ \\
\hline \multicolumn{3}{|l|}{ Education } \\
\hline 12 years & $\begin{array}{c}-0.0995^{*} \\
(0.0540)\end{array}$ & $\begin{array}{c}-0.1828^{* * *} \\
(0.0504)\end{array}$ \\
\hline $13-15$ years & $\begin{array}{c}-0.0197 \\
(0.0665)\end{array}$ & $\begin{array}{c}-0.1806^{* * *} \\
(0.0588)\end{array}$ \\
\hline 16 years & $\begin{array}{c}-0.2227^{* * *} \\
(0.0818)\end{array}$ & $\begin{array}{c}-0.3971 * * * \\
(0.0718)\end{array}$ \\
\hline$>16$ years & $\begin{array}{c}-0.1631 \\
(0.1023)\end{array}$ & $\begin{array}{l}-0.4227^{* * *} \\
(0.1098)\end{array}$ \\
\hline Age & $\begin{array}{c}-0.0045 \\
(0.0190)\end{array}$ & $\begin{array}{c}-0.0200 \\
(0.0173)\end{array}$ \\
\hline Age $^{2}$ & $\begin{array}{c}0.0000 \\
(0.0002)\end{array}$ & $\begin{array}{c}0.0002 \\
(0.0002)\end{array}$ \\
\hline Dependent children in household & $\begin{array}{c}0.0722 \\
(0.0484)\end{array}$ & $\begin{array}{c}-0.0310 \\
(0.0434)\end{array}$ \\
\hline Industry union density & $\begin{array}{c}0.0002 \\
(0.0018)\end{array}$ & $\begin{array}{c}-0.0043^{* *} \\
(0.0018)\end{array}$ \\
\hline State unemployment rate & $\begin{array}{l}0.0300^{* * *} \\
(0.0111)\end{array}$ & $\begin{array}{l}0.0627^{* * *} \\
(0.0170)\end{array}$ \\
\hline $\begin{array}{l}\text { Log likelihood } \\
n\end{array}$ & $\begin{array}{r}-2270.29 \\
9562\end{array}$ & $\begin{array}{r}-2795.70 \\
9314\end{array}$ \\
\hline
\end{tabular}

The specification conforms to column d in Table 2.

***, **. * denote statistical significance at the 0.01 .0 .05 , and 0.10 levels, respectively. 


\section{References}

Addison. John T, Douglas A. Fox, and Christopher J. Ruhm. 1995. Trade and displacemen in manufacturing. Monthly Lubor Review $118.58-67$.

Addison. John T. Douglas A. Fox, and Christopher I. Ruhm. 1996. Trade sensitivity, lechnology, and labor displacement NBER Working Paper No. 5621.

Bean. Charles, Samuel Bentolita. Giuseppe Bertola and Juan Dolado. 1998. Social Europe- Once for All? London: Centre for Economic Policy Research.

Bednarzik, Rohert W. 1993. An analysis of U.S industries sensitive to foreign trade. Monthy Labor Review 104:15-31.

Berman. Eli, John Bound. and Zvi Griliches. 1994. Changes in the demand for skilled labor: Exidence from the annual survey of manufactures. Quarterty Jounal of Exonomics 109:367-97.

Berman. Eli. John Bound, and Stephen Machin. 1997. Implications of skjll-buased technological change: International comparisons. NBER Working Paper No, 6166.

Borjas. George S., and Valerie A. Ramey. 1994. Time-series evidence of the sources of trends in wage inequatity. American Exonumik Review 84:10-6.

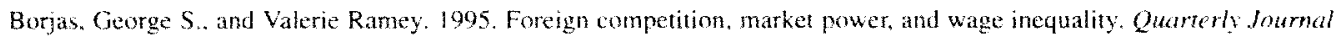
of Economics 110:1075-110.

Burtess. Gary. 1995. International trade and the rise in earnings inequality. Journol of Fonomic Literante $33: 800-16$.

Dickens. Whiliam T. 1988 . The effects of trade on employment: techniques and evidence. In The dynamics of trade and emploment, edited by Laura D'Andrea Tyson, William T. Dickens, and John Zysman. Cambridge. MA: Ballinger, pp. $41-85$.

DiNarto, John E., and Jom-Steflen Pischke. 1997. The returns to computer use revisited: Have pencils changed the wage structure too? Quatery Jounat of Economirs 112:291-303.

Dune, Timothy, and David A. Macpherson. 1994. Unionism and gross employment flows Southem Economic Joumal $60: 727-38$.

Ehrenberg, Ronald G. 1994. Latror markets and integrating national economies. Washingtom. DC: The Brookings Institution.

Farber, Henry S. 1993. The incidence and costs of job loss: 1982-91. Bronkings Papers on Ecomomic Activin Microeconomics: 73119 .

Farber. Henry S. 1997. The changing lace of joh loss in the Unted States: 1981-95. Brookings Papers on Economic Activity Microeconomics:55-128.

Freeman. Richard B. 1995. Are your wages set in Beijing? Joumal of Ecomumic Perspectives 9:15-32.

Freeman, Richard B., and Lawrence F. Katz. 1991. Industrial wage and employment determination in an open economy. In Immigration, trade, and the labor morket. edited by John M. Abowd. Chicago, IL: University of Chicago Press, pp. 235-60.

Freeman. Richard B., and Morris M. Kleiner. 1999. Do unions make enterprises insolvent? Indusirial and Labor Re'tations Revie' $52: 510-27$

Grossman, Gene. 1987. The employment and wage effects of import competition. Joumal of international Economic Integration $2: 1-23$.

Haveman. Jon D 1993. The effect of trade-induced displacement on unemployment and wages. Unpublished Paper, Krannert School of Management. Purdue University.

Herz. Diane E. 1990. Worker displacement in a period of rapid expansion: 1983-87. Monthly Lahor Revit'w 113:21-33.

Hirsch, Barry T., and David A. Macpherson. 1993. Union membership and coverage files from the Current Population Survey: Note. Indastrid and Lahor Relations Reviou 46:574-8.

Jacobson, Louis S. Robert LaLonde, and Daniel Sullivan. 1993. Earnings losses of displaced workers. American Economic Revien 83,685-709.

Juhn. Chinhui, Kevin Murphy. and Rohert Topel. 1991. Why has the natural rate of unemployment increased over time. Browkings Papers on Economic Actialy 2:75-142.

Katz, Lawrence F. Gary W. Loveman, and David G. Blanchflower 1995. A comparison of changes in the structure of wages in four OECD countries. In Differences and chonges in wage structures. edited by Richard B. Freeman. Chicago, IL: University of Chicago Press. pp. 25 65.

Katz. Lawrence F, and Kevin M. Murphy. 1992. Changes in relative wages in the United States. 1963-87: Supply and demand factors. Quarterly Jeumal of Lionomics 107:35-78.

Kletzer, Lori G. 1995a. International trade and displacement in U.S. manufacturing, 1979-1991. Working Paper No 331. University of Calitornia, Santa Cruz.

Kletzer, Lori G. 1995h. What have we learned about job displacement? Working Paper No. 333. Department of Economjes, University of Californa, Santa Cruz.

Krueger. Alan S. 1993. How computers have changed the wage structure: Evidence from microdata. 1984-90. Qharter/. Journat of Economics 108:33-60. 
Krugman, Paul. 1995. Technology, trade, and factor prices. NBER Working Paper No. 5355.

Kruse, Douglas L. 1988. International trade and the labor market experience of displaced workers. Industrial and Labor Relations Review 41:402-17.

Lawrence. Robert Z., and Mathew Slaughter. 1993. Trade and U.S. wages in the 1980s: Giant sucking sound or small hiccup? Brookings Papers on Economic Activity Microeconomics: 161-210.

Leamer, Edward E. 1994. Trade, wages, and revolving door ideas. NBER Working Paper No. 4716.

Machin. Stephen 1996. Changes in the relative demand for skills. In Acquiring skills-Market failures, their symptoms, and policy response's, edited by Alison L. Booth and Dennis J. Snower. Cambridge. England: Cambridge Unjersity Press, pp. $129-46$

Mann, Catherine L. 1988. The effect of foreign competition in prices and quantities on the employment in import sensitive industries. Imemational Trade Joumal 2:409-44.

Mark, Jerome S. 1987. Technological change and employment: Some results from BLS research. Monthly Labor Review $60: 26-9$

Mishel. Lawrence, and Jared Bernstein. 1996. Technology and the wage structure: Has technology's impact accelerated since the 1970s? Washington. DC: Economic Policy Institute.

OECD. 1995. Historical Statistics: 1960-1993. Paris: Organisation for Economic Co-operation and Development.

Revenga. Ana L. 1992. Exporting jobs"? The impact of import competition on employment and wages in U.S. manufacturing. Quarterty Journal of Economics 107:255-84.

Richardson. J. David. 1995. Income inequality and trade: How to think. what to conclude? Joumal of Economic Perspectives $9: 33-56$

Ruhm. Christopher J. 1991. Are workers permanently scarred by job displacements? American Economic Review 81: $319-23$.

Sachs. Jeffrey. and Howard Shatz. 1994. Trade and jobs in U.S. manufacturing. Brookings Papers on Economic Acrivin $1-84$

Schmitt. John, and Lawrence Mishel. 1996. Did international trade lower less-skilled wages during the 1980s? Standard trade theory and evidence. Washington, DC: Economic Policy Institute

Sheiburne, Robert C., and Robert W. Bednarzik. 1993. Geographic concentration of trade sensitive employment. Monthly Labor Review 116:3-13.

Stolper. Wolfgang, and Paul Samuelson. 1941. Protection and real wages. Review of Economic Studies 9:58-73.

U.S. Department of Labor. Bureau of Labor Statistics Geographic profile of employment and unemployment. Washington, DC: U.S. Government Printing Office [1986, 1987. 1990, 1991].

Wood, Adrian. 1994. North-South Trade. Employment, and Inequality: Changing Fortunes in a Skill-Driven World. Oxtord: Clarendon Press.

Wood, Adrian. 1995. How trade hurt unskilled workers Joumal of Economic Perspectives 9:57 80. 